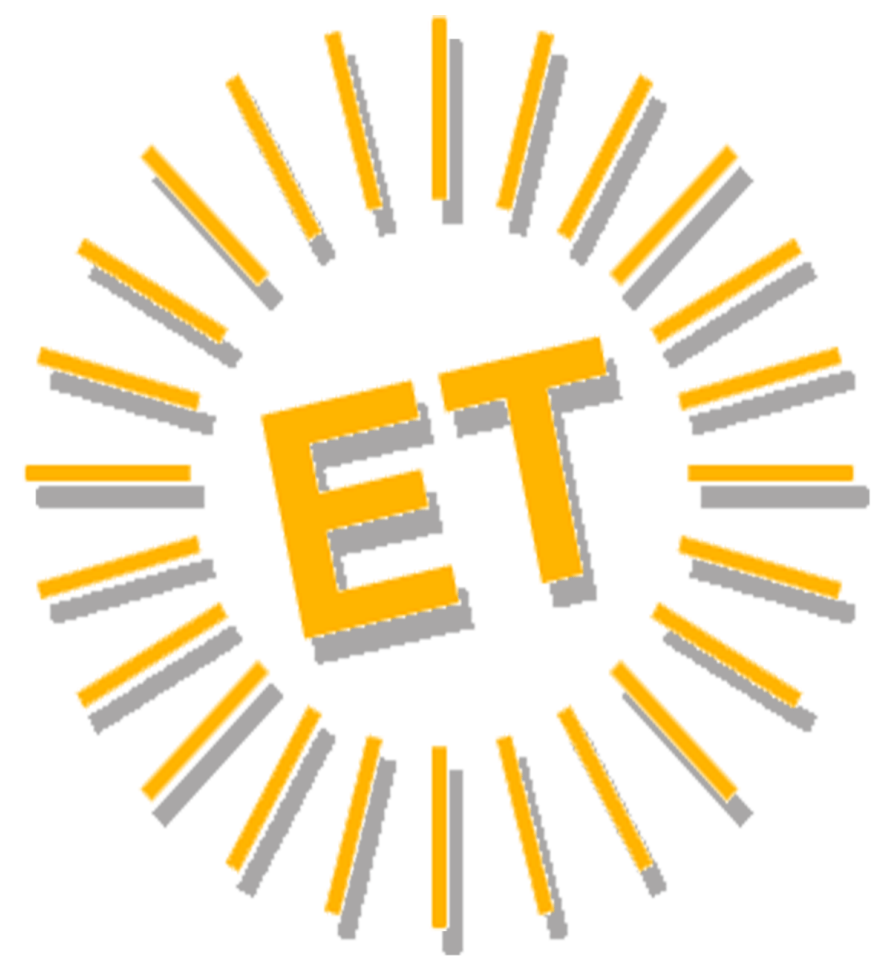




\section{Editorial Team}

\section{Editor in Chief}

Alfonso Vargas-Sánchez, University of Huelva, Spain

\section{Associate Editor}

Mirko Perano, Reald University College, Albania

\section{Books Review Editor}

Brendan Paddison, York St. John University, United Kingdom

\section{Secretariat}

Elena García de Soto, University of Huelva, Spain

Cinta Borrero-Domínguez, University of Huelva, Spain

\section{Style reviewer and text editor}

Anestis Fotiadis, I-SHOU University, Taiwan, Province of China

\section{Editorial Board}

José Manuel Alcaraz, Murdoch University, Australia Mario Castellanos-Verdugo, University of Seville, Spain José Antonio Fraiz-Brea, University of Vigo, Spain José Manuel Hernández-Mogollón, University of Extremadura, Spain

Tzung-Chen Huan, National Chiayi University, Taiwan, Province of China

Shaul Krakover, Ben Gurion University, Israel Jean Pierre Levy-Mangin, University of Quebec, Canada Tomás López-Guzmán, University of Córdoba, Spain Yasuo Ohe, Chiba University, Japón María de los Ángeles Plaza-Mejía, University of Huelva, Spain Nuria Porras-Bueno, University of Huelva, Spain João Albino Silva, Algarve University, Portugal

\section{Advisory Board (Spanish Members)}

Juan Manuel Berbel-Pineda, Pablo de Olavide University, Spain César Camisón-Zornoza, Uniersity of Valencia, Spain Enrique Claver-Cortés, University of Alicante, Spain María Teresa Fernández-Alles, University of Cádiz, Spain José Luis Galán-González, University of Seville, Spain Félix Grande-Torraleja, University of Jaén, Spain

Antonio Leal-Millán, University of Seville, Spain Inmaculada Martín-Rojo, University of Málaga, Spain Antonio Manuel Martínez-López, University of Huelva, Spain Francisco José Martínez-López, University of Huelva, Spain Pablo A. Muñoz-Gallego, University of Salamanca, Spain
Francisco Riquel-Ligero, University of Huelva, Spain José Miguel Rodríguez-Antón, Autonomous University of Madrid, Spain

Sandra Sanchez-Cañizares, University of Cordoba, Spain Josep Francesc Valls-Giménez, ESADE, Spain

\section{Advisory Board (Other European Members)}

Tindara Abbate, University of Messina, Italy Paulo Aguas, University of Algarve, Portugal Carlos Costa, Aveiro University, Portugal Dianne Dredge, Aalborg University, Denmark Salvatore Esposito de Falco, University of Rome "La Sapienza", Italy

Sheila Flanagan, Dublín Institute of Technology, Ireland Tania Gorcheva, Tsenov Academy of Economics, Bulgaria Tadeja Jere Jakulin, University of Primorska, Slovenia Metin Kozak, Mugla University, Turkey Álvaro Matias, Lusiada University, Portugal Alfonso Morvillo, National Research Council, Italy Alexandru Nedelea, Stefan cel Mare University of Suceava, Romania

Claudio Nigro, University of Foggia, Italy

Angelo Presenza, University "G. D'Annunzio" of Chieti-Pescara, Italy

Kanes Rajah, Royal Agricultural University, United Kingdom

\section{Advisory Board (Members from the rest of the world)}

John Allee, American University of Sharjah, United Arab Emirates

Nestor Pedro Braidot, National University of La Plata, Argentina

Roberto Elias Canese, Columbia University, Rector, Paraguay

Luca Casali, Queensland University of Technology, Australia Nimit Chowdhary, Indian Institute of Tourism and Travel Management, India

Steven Chung-chi Wu, National Pingtung University of Science and Technology, Taiwán

Dianne Dredge, Southern Cross University, Australia Daniel Fesenmaier, Temple University, United States

Babu George, Alaska Pacific University, United States Dogan Gursoy, Washington State University, United States Jafar Jafari, University of Wisconsin-Stout, United States Sanggun Lee, Pai Chai University, Korea Republic of Albert Yeh Shangpao, I-SHOU University, Taiwán Pauline Sheldon, University of Hawaii, United States Germán A. Sierra-Anaya, University of Cartagena de Indias, Rector, Colombia Xiaohua Yang, University of San Francisco, United States 


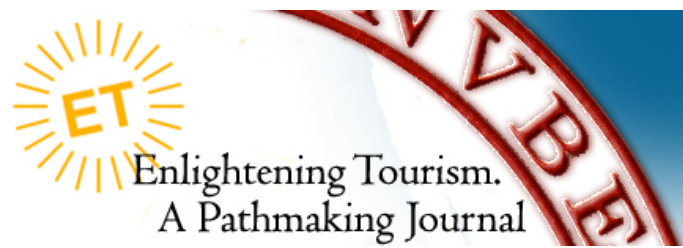

\title{
TOWARDS SOCIALLY SUSTAINABLE TOURISM IN CITIES: LOCAL COMMUNITY PERCEPTIONS AND DEVELOPMENT GUIDELINES
}

\author{
Filipa Pinto da Silva \\ School of Hospitality and Tourism of Polytechnic of Porto (Portugal) \\ filipasilva.afcps@outlook.com
}

Filipa Brandão

University of Aveiro (Portugal)

filipa.brandao@ua.pt

\begin{abstract}
Bruno Sousa
Polytechnic Institute of Cávado and Ave - IPCA (Portugal)

bsousa@ipca.pt
\end{abstract}

\begin{abstract}
In the last years, tourism has been growing significantly in urban settings. This growth led to a number of positive impacts, but the uncontrolled expansion of tourism related activities (the 'overtourism' effect) has caused many negative outcomes. This paper entails a reflection on sustainable tourism in urban contexts, focusing on locals' perceptions of tourism impacts on their daily lives. A survey was conducted of 151 residents and workers of the city centre of Porto, Portugal, aiming at a deeper understanding of the social, cultural, and economic, impacts resulting from the exponential development of tourism in the city. The findings suggest that, at this early stage of development, locals agree with the development of tourism in the city and consider that it improved their overall living conditions. However, there are concerns with housing prices and rising cost of living. The resulting data allowed to design a set of guidelines to build a sustainable development model for urban tourism destinations, assuring the local communities' quality of life, where several
\end{abstract}


preventive measures are presented that aim to preserve the sociocultural sustainability of urban communities.

KEYWORDS

Urban tourism; Residents' perception; Tourism impacts; Overtourism;

Sustainable development.

ECONLIT KEYS

Z32; Z38; Q01; O29

\section{INTRODUCTION}

In 2017, urban tourism in Europe grew 7.7\%, especially boosted by international markets (ECM, 2018). This rate demonstrates a hyperactive growth and, in many European cities, a disruptive moment for the industry is occurring: alongside the rising numbers of tourists, issues regarding the impacts of tourism are also growing (Postma \& Schmuecker, 2017; Martín, Martínez \& Fernández, 2018). At the same pace private investment in urban rehabilitation is increasing, there are voices shouting against gentrification. There is a significant discussion on "touristification", massification and loss of authenticity in urban centres (Minoia, 2016; Martín, Martínez \& Fernández, 2018). The reasons for the rise of arguments and actions against tourism include, according to Seraphin, Sheeran \& Pilato (2018), the excessive number of visitors endangering the UNESCO World Heritage status; tourists are impacting negatively on the residents' quality of life; the environmental sustainability of destinations is being jeopardised; and the positive contribution of day trippers to local legal businesses is often limited. The growth of uncontrolled and unplanned tourism in urban settings is being highly debated by academics, politicians, and citizens. However, there is little research on how models of urban tourism development might be shaped. If, on one hand, the excessive growth of city tourism can bring severe negative consequences, it is also acknowledged that it may also bring economic, social, and cultural positive impacts, and thus assuring destinations' sustainability. In this case, locals may understand tourism as a positive activity and welcome its further development, provided that negative impacts are mitigated. The lack of such insight is a critical gap in the literature, as there is little or no evidence on how city tourism development models should be designed in order to promote city's sustainable tourism development. 
This paper aims at analysing the impacts of tourism development in urban contexts, how they are felt by both residents and workers, and which sustainable development guidelines should be implemented in these settings, considering that most sustainable development models are focused on the environmental dimension and applied to natural, protected or coastal destinations.

Specifically, it is intended to: i) Understand the positive and negative impacts of tourism development in urban contexts; ii) Analyse the perceptions and attitudes of city centres' residents and workers towards tourism development and the resulting impacts; iii) Through the analysis of the data collected, to present development guidelines based on preventive measures, to maximize the positive impacts of tourism and minimize the negative ones, assuring the sustainable development of tourism in cities.

In order to achieve this, data was collected from city centre residents and workers, with the objective of gathering information regarding their perception about tourism development and its impacts. Information on household dependency on tourism was also gathered.

This research allowed to conclude that the greater the family dependency of this industry, the greater the predisposition to have a more positive perception about tourism development. It is also understood that gentrification and "touristification" are frequent phenomena in historical centres with a great focus on tourism activity and that, therefore, housing prices are one of the main causes of population dissatisfaction. In this way, it is believed that measures aimed at integrating the community into tourism industry projects that promote a fair distribution of incomes and greater awareness of visitors, could have very positive effects on receiving communities.

The paper is organized as follows: first, the literature about trends on urban tourism and its main challenges is reviewed, stressing the phenomenon of gentrification and residents' quality of life. The following section presents a characterisation of the territory under study, the city of Porto, Portugal. Subsequently, in the methodology section, the objectives, hypothesis, sampling procedures, and data collection methods and techniques are identified. Finally, research findings are reported and discussed, and their implications for further research and applications are highlighted. 


\section{LITERATURE REVIEW}

\section{1) URBAN TOURISM DEVELOPMENT: TRENDS AND CHALLENGES}

In the mid-1970s, the traditional conception of the city changed. Cities started to become centres of attraction for tourists and consolidating as tourist destinations. During the past thirty years, the most common local development strategies in cities have been the support of tourism industry as a vehicle for urban economic improvement and growth (Rogerson \& Rogerson, 2014).

According to Pearce (2001), urban tourism has emerged as a significant and distinctive field of study during the 90 s and this increase in attention in part reflects the growth of tourism in cities and its resulting associated policy issues. The last decades have seen significant changes in urban tourism planning and development. However, its complexity, deriving from its multifunctionality, may have delayed important research in the field. In result, as Blank (1994, pp. 185) notices, urban tourism industry has received less support than desired. Despite its importance and exponential growth worldwide, urban tourism phenomenon remains unexplored (Füller \& Michel, 2014).

Despite this, Gilbert \& Clark (1997) state that urban tourism, as a filed of study, is just as valid as other conceptual definitions previously accepted in the study of tourism. Synthetically, it is understood that the effort of urban tourism focuses on the study of the interrelations between tourism and the urban environment.

From the perspective of Ashworth \& Page (2011), there is a clear disharmony between the interests of tourism and the interests of the host cities. This is because tourists use many urban facilities and services intensively, but it is noted that few cities are specifically designed for tourist use. On the other hand, it is important to clarify that tourism is considered as a lever for urban regeneration and for the recovery of historic and often declining areas of cities (Rogerson \& Rogerson, 2014). Many urban tourism projects are funded by private sector or promoted by public sector with the support of private firms (Brouder \& Ioannides, 2014) which limits opportunities and may exclude access to locals. It is thus important to determine what approaches will be most beneficial to the general public, both residents and visitors (Wise, 2016).Ashworth (2011) acknowledges that tourism may represent substantial economic benefits for cities, but cities whose economies are more 
dependent on tourism are the ones with less economic profit. Paskaleva-Shapira (2007) emphasize the increasing importance of dealing with the industry with special attention to the urban economy, environment, society, and cultural specificities.

The changes in the paradigm of urban tourism in recent years have forced tourism organisations to rethink their management systems. Subsequently, PaskalevaShapira (2007) presents the main challenges for urban destinations, namely the development of competitive and sustainable destinations; management of urban tourism systems; the creation of quality urban tourism and the use of marketing to increase the attractiveness of cities. World Tourism Organization (UNWTO, 2012) also recognises that the fleeting growth of the tourism sector in an urban context necessarily represents contemporary trends that bring new challenges. The organization considers that it is only possible to respond to future challenges through the joint learning of the various stakeholders of the destinations and the medium-term strategic planning, setting limits for development. It is suggested that effective, wellmanaged and balanced cooperation is essential if tourism income is to benefit all parties involved. Thus, residents' perceptions of tourism development are crucial, not only for the new socially responsible and concerned tourists seeking for preservation and authenticity, but also for the emergence of new planning and management models that take the residents' wellbeing into consideration. It is on this assumption that this research is based and on which the study is developed.

\section{2) THE PHENOMENA OF GENTRIFICATION AND “TOURISTIFICATION”}

Mendes (2014) defines gentrification as a process of socio-spatial changes, where the rehabilitation of residential properties situated in popular or traditional neighbourhoods attracts the establishment of new residents with relatively high financial capacity, thus provoking the displacement of ex-residents due to their inability to keep pace with the increase in housing costs associated with the urban rehabilitation process.

Herzer (2008) believes that gentrification creates the necessary conditions in environment and the market to increase the average income within an urban space, district, or neighbourhood, but at the same time, it counteracts rising income with negative actions such as exclusion and social discriminatory practices. According to 
Skoll \& Korstanje (2014), as a result of this, feelings of resentment and conflict arise. Some scholars insist on defending gentrification because it revitalizes the infrastructure, helping neighbourhoods and expanding community wellbeing. Nonetheless, financial loans that facilitate access to property are not affordable to lower classes of working people. Gentrification occurs through a combination of private and state policies such as urban refurbishment, tax regulation, real-estate speculation, private investment, and tourism that encourages the heritagization of spaces (Skoll \& Korstanje, 2014).

Gentrification relates to tourism, because as soon as the city becomes attractive due to the industry growth and there are public and private investments aiming at rehabilitating urban centres - construction of new tourist accommodation, new commercial spaces for tourism consumption - residents are forced to leave their homes in result of the rising living costs. This way, a type of social "selection" arises, where the most disadvantaged people are forced to move to the peripheries (Mendes, 2014). The growth and diversification of tourists leads to the emergence of neighbourhoods as new tourism areas being promoted by authorities for their vibrant scene and authentic feeling (Botelho et al., 2014; Janoschka, Sequera \& Salinas, 2014).

Gravari-Barbas \& Guinand (2017) sustain that tourism gentrification is a shaping force of socio-economic and contemporary urban landscapes, not only by the absence of residents and by the abundance of short term rental accommodation, as well as in the changing landscape at the level of commerce and business that emerge for a new target audience: the tourist.

The "touristification" thus occurs with the arrival of tourists in substantial numbers and the abandonment of the cities by the residents (Issa \& Dencker, 2006). It emerges when the tourist destination is just that - tourists, with the subsequent the loss of authenticity. Gentrification and "touristification", both as concepts and processes, are inseparable. In tourism destinations, one phenomenon leads to the other, which in turn leads to a loss of identity and amplifies the cities' sociocultural problems.

Doug Lansky, an American who has known more than 100 countries and wrote several articles and travel guides, in an interview to a Portuguese newspaper (Lansky, 2017) states that, in the face of the rapid development of world tourism, "these places are increasingly equal to Venice and to become a city without a soul. 
The true soul of a city, what makes it authentic is people and their natural rhythm. When you get too many visitors inside you will lose that authenticity".

\section{3) TOURISTIFICATION, HERITAGE AND QUALITY OF LIFE}

Tourism development should be implemented in line with sustainability of tourism strategies and equally distributed for social, environmental, and economic benefits to all the community's stakeholders (Li \& Wan 2013; Nunkoo \& Gursoy 2012; Jeon, Kang \& Desmarais, 2016; Seraphin, Yallop, Capatîna \& Gowreesunkar, 2018). Several studies have discussed the major aspects of tourism, such as economic benefits, social concerns, environmental sustainability, and their impacts on residents' attitudes or perceptions toward tourism in the host community (Choi \& Sirakaya, 2005; Yu et al., 2011).

An important issue deriving from the excess of tourism is related to authenticity, and how to assure its preservation as part of cultural heritage and social life (Belhassen, Caton \& Stewart, 2008; Kim \& Jamal, 2007).

Although residents appreciate the benefits that tourism brings to the community, they face several challenges in their daily lives while competing with tourists for scarce resources (Jeon et al., 2016).

According to Jeon, Kang \& Desmarais (2016), several studies assessed the impacts of tourism on residents' quality of life (Nawijin, 2011; Sirgy et al., 2011) because tourism affects residents' perceptions of well-being as well as quality tourism experiences of tourists within a host community. Uysal et al. (2012) concluded that residents' quality of life has been increasingly recognised as the perception of happiness of well-being with their life domains and thus should be conceptualized as the aggregation of residents' perception of economic, social, and environmental conditions as well as global perception of well-being in the host community. The perception of high quality of life by locals results in positive attitudes towards tourism and tourists, which leads to sustaining economic and social contributions to the community in specific tourism contexts (Jeon, Kang \& Desmarais, 2016).

Globally, literature reveals that the residents' perception of tourism impacts is directly related to the benefits that they obtain from it (Andereck, Valentine, Knopf \& 
Vogt, 2005; Lundberg, 2017). Guerreiro, Mendes, Valle \& Silva (2008) sustain that when tourism positively influences the community, the attitude towards the industry turns out to be positive. When they do not receive any returns from the activity, then the negative impacts seem to be more noticeable. Being locally involved increases social integration and create mutual understanding regarding economic and sociocultural impacts (Lundberg, 2017).

Thus, four hypotheses are advanced:

H1: Local community's perception of tourism economic impacts diverges according to their economic involvement in the tourist industry.

H2: Local community's perception of tourism socio-cultural impacts diverges according to their economic involvement in the tourist industry.

H3: Local community members that are economically involved tourism have more positive feelings and attitudes towards it.

H4: Urban residents' perceptions and attitudes towards tourism depends on its stage of development.

\section{STUDY-SITE CONTEXT: THE CITY OF PORTO AS A TOURISM DESTINATION}

Portugal is experiencing a "golden" time in terms of tourism growth and there is already a great economic dependence on the sector. In August 2017, tourism represented 7\% of the Gross Domestic Product (GDP) (Bexiga, 2017; Ribeiro \& Pinheiro, 2018).

Porto is the second most important city in Portugal in terms of population and economic significance and has been acknowledged as an important tourism destination in recent years. It is located in the North of the country, in the coastline. Despite its seaside location, it is not relevant or searched for beach tourism. Its recent development as tourism destination results from a combination of several factors. In fact, the city has undergone significant physical, cultural, and social transformations. In 1996, the historic centre was declared World Heritage Site by UNESCO and in 2001 was chosen as European Cultural Capital. Several awards and distinctions have been granted to the city by worldwide renowned media. These endeavours fostered the investment in real estate and in the improvement of urban public spaces and infrastructures, as well as the emergence of several events. The settlement of several low-cost airlines, linking the city of dozens of European cities, 
alongside the international buzz in the media, also had a strong impact in the growth of tourists' arrivals. The result was a renewed Porto whose development is strongly attached to Tourism growth. The city is now internationally recognised as a cosmopolitan destination (Ramires, Brandão \& Sousa, 2017).

Nowadays, Porto registers 3.3 million overnight stays, out of which $76.4 \%$ are by international tourists (INE, 2017). The main international markets are Spain, France, Germany, and UK. Domestic market account for $23.6 \%$ of all overnights. For the purpose of this study, it is important to present some relevant dynamics of the city. The first regards the enormous growth of tourism demand and supply. In 10 years, overnights increased 153\%, and the number of beds grew 170\% (INE, 2007; 2017). Porto welcomes 4,500 tourists per day and 228 tourists per square kilometre. There are eight tourists per resident. These numbers are even higher than cities like London and Barcelona and it should be mentioned that most tourists are concentrated in an area of two to three square kilometres (Público, 2017). These numbers confirm the rapid growth of tourism, causing significant impacts, both positive and negative. Positive impacts derive from the extraordinary recovery of the city centre, a formerly degraded area, empty of economic activities, residents, or cultural and social life, to become a cosmopolitan and live space, where historic buildings, public spaces and lodging were rehabilitated, filled with restaurants, stores, hotels, businesses, a younger population, and increased employment. Negative impacts relate to the exit of the residents from the city centre to the peripheries, due to the rising prices of real estate, as well as the saturation of services due to the drastic increase of the tourist community. The city accommodates, according to the last censuses, 237,591 residents (INE, 2013), a decrease of 9.7\% when compared to 2001 data (INE, 2002). Even though there is no data on the population employed in tourism, it is known that there is a growth in employment rate that is parallel to the tourism boost in the city. This study will analyse its impacts alongside Porto's residents and workers and conclude on their perceptions regarding tourism development, in order to propose socially sustainable development guidelines for touristic cities.

\section{RESEARCH METHODOLOGY}


This research is based on an exploratory study. As stated by Veal (2006), exploratory studies are applied in topics which have not previously been sufficiently studied or when patterns are constantly changing and relate to many of the descriptive research in tourism. This research is a quantitative study set on a questionnaire-based survey applied to residents and workers of the city centre of Porto, which is where tourism development is mainly felt. However, it may be considered that a two-fold mix-method approach was used, since qualitative methods are also applied. Documentary films about European cities where overtourism is a reality were analysed, namely the interviews to their residents. These were subject to content analysis to extract the perceptions and attitudes towards tourism development in territories where negative impacts are already felt. This method was the basis for the development of a part of the survey.

\section{1) DATA COLLECTION AND ANALYSIS}

A questionnaire-survey was designed according to Andereck et al.'s (2005) perspective on tourism development. The authors consider that the consequences of tourism development can be divided into three broad categories: economic, environmental, and socio-cultural impacts, following the definition of sustainable development. Bearing this in mind, respondents were asked to state whether they agree or disagree with a set of statements, resulting from literature review, regarding the three above-mentioned dimensions. A five-point Likert scale was used to classify their accordance with:

i) Economic impacts, such as employment and wealth creation, increase of family income, rising of prices, tourists spending;

ii) Socio-cultural impacts, namely the influence of tourism in heritage conservation, cultural activities, quality of life, traffic, criminality, prostitution, drug consumption, in residents being forced to leave their homes, and the quality of interaction between tourists and locals.

In the second part of the survey, a different method was used. After the identification and analysis of several film documentaries about "touristification" in European cities, such as Venice and Barcelona, cities that are currently in a much more advanced stage of tourism development when compared with their Portuguese counterparts, it was concluded that there are little empirical findings on the specific 
perceptions and feelings of local population towards this development. In an exploratory case study and resorting to content analysis, the interviews given by these residents in the documentaries were subject to content analysis, classified according to the type of impact (economic or socio-cultural), and transformed into feelings/statements. Respondents of our survey were then asked to demonstrate to which extent (five-point Likert scale) they share the opinion of these interviewees regarding tourism impacts in their quality of life. Finally, the third part included open questions where respondents were free to present their ideas about tourism impacts in the city and the potential measures that they think should be developed by tourism authorities.

The street survey was conducted between May and August 2017 and was personally administered by the researchers to residents and workers of Porto's city centre parishes, the place where tourism is most concentrated, and its impacts are felt. Adopting a convenience sample selection technique, a first approach was made to people in the streets and commercial spaces, to classify them as residents or workers. If none was the case, they were disregarded for the study.

As a quantitative study, data was analysed to test the defined hypothesis and to fulfil the research objectives. Besides the descriptive analysis of the responses, latent variables based on the average of responses of the items of economic impacts and of social impacts were created, and the differences of opinion between those who are professionally involved in tourism, and those who are not were analysed resorting to the Mann-Whitney non-parametric test. Contingency tables and Pearson $X^{2}$ tests were computed to analyse the association between variables comprising the economic and socio-cultural impacts dimensions. Finally, the agreement with the statements of overcrowded tourism cities and present in the analysed documentaries, was also considered, applying a five-point Likert scale. The resulting data allowed to design a set of guidelines to build a socially sustainable development model for urban tourism destinations, assuring the local communities' quality of life.

\section{2) SAMPLE}

The technique used to collect data was based on the 'street survey'. Street survey is a means of contacting a representative sample of the community or visitors to an 
area (Veal, 2006), and thus it was considered as adequate to the objectives of this research. A convenience sample was used. Interviewers were located in the city centre and approached people passing by in order to survey them, in the condition of being residents or workers in that place.

\begin{tabular}{llll}
\hline Variables & & $\%$ & Average \\
\hline Age & & & 33,3 \\
\hline Gender & Women & 68.2 & \\
& Men & 31.8 & 10.6 \\
\hline Education level & Basic education & 25.8 \\
& High school & 38.4 \\
& Graduate & 23.8 \\
& Master & 1.3 \\
\hline Monthly income & of & 45 \\
the household & PhD -1000€ & 36.4 \\
& $1000-2000 €$ & 11.9 \\
& $2000-3000 €$ & 4.0 \\
& $3000-4000 €$ & 1.3 \\
\hline Occupation & $5000 €$ or more & 36 \\
& Tourism related & 64 \\
\hline Occupation of & Not tourism related & Tourism related & 17.2 \\
household members & Not tourism related & 82.8 \\
\hline \multicolumn{4}{c}{ Table 1. Characterization of the sample } \\
Source: own elaboration.
\end{tabular}

A total of 151 individuals aged between 18 and 83 years were surveyed (Table 1). The respondents are mainly women (68.2\% vs. 31.8\%), aged between 18 and 83 years old, with higher education degrees. Despite their educational level, the monthly income of the household is lower than $2000 €$ for nearly $81 \%$. Only $36 \%$ of the respondents work directly or indirectly with tourism, despite the growth of the industry in the city.

According to the World Tourism Organization (UNWTO \& SNV, 2010) part of the profits of tourism should benefit the poorest groups in society through employment in tourism companies, goods and services provided to tourists or through the operation of small community enterprises. This value of $36 \%$ may be increased in order to assure that residents effectively benefit from tourism revenues and are included in the development model. In this context, over-reliance on tourism employment should be considered in development strategies in order to avoid it. Despite this, urban tourism is not seasonal as other types of tourism, nor experiences severe decrease 
rates. Thus, negative effects of higher employment rates in tourism industry should not create significant problems.

\section{MAIN RESULTS}

The following results portray the residents' perception of tourism impacts in Porto. The city started to feel the tourism development around a decade ago, being thus in an early stage of development, despite the many tourists visiting the city. It is understood that, although the phenomena of gentrification and touristification (Mendes, 2014) are already felt and acknowledged by the community, there is no feeling of disharmony regarding the satisfaction of the tourist and the well-being of the resident community.

Respondents demonstrate that there is a slight sense of injustice as to the way tourism profits are distributed, but it is also clear that the population believes that without tourism the city would (still) have serious security problems, less job opportunities and fewer cultural prospects. Dwyer et al. (2009) argue that tourism and tourists have changed over time. Today's visitors want to relate to the host community and share their experience with the locals, which may open the opportunity to maximise positive impacts and to maintain authenticity, avoiding gentrification. Respondents reveal that one of the most positive aspects of tourism development is the relationship with tourists and the sharing of experiences with other cultures. The community shows to be extremely positive about the contact with visitors. In fact, a first and relevant result of the study is that $73.5 \%$ of respondents agree or fully agree with tourism development in the city Porto, regardless of working in the industry or not (Table 2).

\begin{tabular}{|c|c|c|c|c|c|}
\hline \multirow{2}{*}{ Variables } & \multirow{2}{*}{$\begin{array}{c}\text { Level of } \\
\text { agreement }\end{array}$} & \multirow{2}{*}{$\%$} & \multicolumn{3}{|c|}{ Pearson $X^{2}$ Test } \\
\hline & & & Value & df. & Sig. \\
\hline \multirow{5}{*}{$\begin{array}{l}\text { Tourism generates } \\
\text { increased employment } \\
\text { rates for residents }\end{array}$} & Fully agree & 22 & \multirow{5}{*}{7.703} & \multirow{5}{*}{4} & \multirow{5}{*}{.103} \\
\hline & Agree & 53 & & & \\
\hline & Undecided & 12 & & & \\
\hline & Disagree & 11 & & & \\
\hline & $\begin{array}{l}\text { Fully } \\
\text { disagree }\end{array}$ & 2 & & & \\
\hline \multirow{3}{*}{$\begin{array}{l}\text { Tourism brings wealth to } \\
\text { the historic centre of the } \\
\text { city }\end{array}$} & Fully agree & 22 & \multirow{3}{*}{16.075} & \multirow{3}{*}{7} & \multirow{3}{*}{.024} \\
\hline & Agree & 49 & & & \\
\hline & Undecided & 14 & & & \\
\hline
\end{tabular}




\begin{tabular}{|c|c|c|c|c|c|}
\hline & $\begin{array}{l}\text { Disagree } \\
\text { Fully } \\
\text { disagree }\end{array}$ & $\begin{array}{l}7 \\
7\end{array}$ & & & \\
\hline \multirow{5}{*}{$\begin{array}{l}\text { Tourism has increased } \\
\text { family income }\end{array}$} & Fully agree & 9 & \multirow{5}{*}{31.106} & \multirow{5}{*}{4} & \multirow{5}{*}{000} \\
\hline & Agree & 8 & & & \\
\hline & Undecided & 9 & & & \\
\hline & Disagree & 22 & & & \\
\hline & $\begin{array}{l}\text { Fully } \\
\text { disagree }\end{array}$ & 53 & & & \\
\hline \multirow{6}{*}{$\begin{array}{l}\text { The cost of living } \\
\text { increased due to tourism }\end{array}$} & Fully agree & 46 & \multirow{6}{*}{11.692} & \multirow{6}{*}{6} & \multirow{6}{*}{.069} \\
\hline & Agree & 34 & & & \\
\hline & Undecided & 13 & & & \\
\hline & Disagree & 5 & & & \\
\hline & $\begin{array}{l}\text { Fully } \\
\text { disagree }\end{array}$ & 0,7 & & & \\
\hline & $\begin{array}{l}\text { Don't know } \\
\text { / Don't } \\
\text { answer }\end{array}$ & 0,7 & & & \\
\hline \multirow{5}{*}{$\begin{array}{l}\text { Tourism benefits only a } \\
\text { limited number of } \\
\text { residents }\end{array}$} & Fully agree & 17 & \multirow{5}{*}{9.571} & \multirow{5}{*}{4} & \multirow{5}{*}{.048} \\
\hline & Agree & 38 & & & \\
\hline & Undecided & 18 & & & \\
\hline & Disagree & 22 & & & \\
\hline & $\begin{array}{l}\text { Fully } \\
\text { disagree }\end{array}$ & 6 & & & \\
\hline
\end{tabular}

Previous studies confirm that economic tourism impacts are perceived by residents as a mean to generate employment, improve local economy and increase investments (Pham \& Kayat, 2011). On the other hand, there is a dark side of it, portrayed in the increase in the cost of living and the feeling of injustice regarding the distribution of profits generated by tourism (Afthanorhan, Awang \& Fazella, 2017). Data shows that respondents feel that tourism has increased employment rates, but they do not agree that family incomes have increased significantly. It is noted that Porto's residents agree that tourism incomes do not benefit the entire community as it should or could (Table 2). This calls for measures to maximise the participation of host community in tourism economic benefits.

Pearson's $X^{2}$ test demonstrates that the fact of being professionally involved in tourism, or having a family member who is, influences the perception that tourism brings wealth to the (otherwise poor and degraded) city centre, that it allows to increase the family income and it benefits only a limited number of residents. Subsequently, in order to validate hypothesis 1 , the data on economic impacts was transformed into a latent variable to analyse the overall perception of residents and workers. Thus, variables were crossed to confirm if the opinion of the respondents 
about the economic impacts of tourism in the city is influenced by their or their family members professional activity. The results of Mann-Whitney test allowed to conclude that the perception of economic impacts differs between those who are professionally involved in tourism, from those who are not (Sig. = 0.026), validating Hypothesis 1 (Local community's perception of tourism economic impacts diverges according to their economic involvement in the tourist industry). Respondents that perform functions linked to tourism, or that have close family members doing so, are more positive towards economic impacts resulting from tourism development, than the others. Those who work in tourism have more positive reaction to issues related to the increase in family income, the distribution of tourist incomes among the population and the increase of jobs due to tourism growth.

In the current research, responses demonstrate that the residents believe that issues as crime, prostitution and drug use are not result of tourism development, as most of the respondents disagree or fully disagree with these statements (Table 3). The historic centre of Porto was, a few years ago, a very old and degraded part of the city, living on traditional retail stores and banks during the day, with mostly older people inhabiting there, and remaining empty at night. At these stage, drugs, crime, and prostitution were serious problems, which have practically disappeared with tourism development. Mann-Whitney test reports that the differences of opinion between those that are professionally involved in tourism and those who are not regarding tourism's overall socio-cultural impacts are not statistically significant (Sig. $=0.291$ ). According to this result, hypothesis 2 (Local community's perception of tourism socio-cultural impacts diverges according to their economic involvement in the tourist industry) is rejected.

\begin{tabular}{|c|c|c|c|c|c|}
\hline \multirow{2}{*}{ Variables } & \multirow{2}{*}{$\begin{array}{c}\text { Level of } \\
\text { agreement }\end{array}$} & \multirow{2}{*}{$\%$} & \multicolumn{3}{|c|}{ Pearson $X^{2}$ Test } \\
\hline & & & Value & df. & Sig. \\
\hline \multirow{5}{*}{$\begin{array}{l}\text { Tourism contributes to } \\
\text { heritage and public spaces } \\
\text { conservation }\end{array}$} & Fully agree & 16 & \multirow{5}{*}{5.299} & \multirow{5}{*}{4} & \multirow{5}{*}{.258} \\
\hline & Agree & 48 & & & \\
\hline & Undecided & 17 & & & \\
\hline & Disagree & 17 & & & \\
\hline & Fully disagree & 7 & & & \\
\hline \multirow{5}{*}{$\begin{array}{l}\text { Tourism brings more } \\
\text { cultural activities to Porto }\end{array}$} & Fully agree & 48 & \multirow{5}{*}{4.397} & \multirow{5}{*}{4} & \multirow{5}{*}{.355} \\
\hline & Agree & 17 & & & \\
\hline & Undecided & 17 & & & \\
\hline & Disagree & 7 & & & \\
\hline & Fully disagree & 3 & & & \\
\hline Tourism has been & Fully agree & 20 & 2.342 & 4 & .673 \\
\hline
\end{tabular}




\begin{tabular}{|c|c|c|c|c|c|}
\hline \multirow{6}{*}{$\begin{array}{l}\text { Variables } \\
\text { detrimental to the quality of } \\
\text { life of residents of the } \\
\text { historic centre of Porto }\end{array}$} & \multirow{2}{*}{$\begin{array}{l}\text { Level of } \\
\text { agreement }\end{array}$} & \multirow{2}{*}{$\%$} & \multicolumn{3}{|c|}{ Pearson $X^{2}$ Test } \\
\hline & & & Value & df. & Sig. \\
\hline & $\begin{array}{ll}\text { Agree } & 34\end{array}$ & \multicolumn{4}{|l|}{34} \\
\hline & Undecided & \multicolumn{4}{|l|}{15} \\
\hline & Disagree & \multicolumn{4}{|l|}{20} \\
\hline & Fully disagree & \multicolumn{4}{|l|}{11} \\
\hline \multirow{5}{*}{$\begin{array}{l}\text { Crime has increased with } \\
\text { the growth of tourism }\end{array}$} & Fully agree & 7 & \multirow{5}{*}{3.288} & \multirow{5}{*}{4} & \multirow{5}{*}{.511} \\
\hline & Agree & 11 & & & \\
\hline & Undecided & 21 & & & \\
\hline & Disagree & 44 & & & \\
\hline & Fully disagree & 15 & & & \\
\hline \multirow{5}{*}{$\begin{array}{l}\text { Tourism has led to a } \\
\text { decreased in the number of } \\
\text { residents in the city centre }\end{array}$} & Fully agree & 34 & \multirow{5}{*}{4.584} & \multirow{5}{*}{4} & \multirow{5}{*}{.333} \\
\hline & Agree & 26 & & & \\
\hline & Undecided & 18 & & & \\
\hline & Disagree & 17 & & & \\
\hline & Fully disagree & 5 & & & \\
\hline \multirow{5}{*}{$\begin{array}{l}\text { Traffic problems have } \\
\text { increased with tourism }\end{array}$} & Fully agree & 29 & \multirow{5}{*}{1.563} & \multirow{5}{*}{4} & \multirow{5}{*}{.815} \\
\hline & Agree & 26 & & & \\
\hline & Undecided & 21 & & & \\
\hline & Disagree & 17 & & & \\
\hline & Fully disagree & 7 & & & \\
\hline \multirow{5}{*}{$\begin{array}{l}\text { Prostitution has increased } \\
\text { due to tourism }\end{array}$} & Fully agree & 3 & \multirow{5}{*}{8.716} & \multirow{5}{*}{4} & \multirow{5}{*}{.069} \\
\hline & Agree & 9 & & & \\
\hline & Undecided & 31 & & & \\
\hline & Disagree & 40 & & & \\
\hline & Fully disagree & 21 & & & \\
\hline \multirow{5}{*}{$\begin{array}{l}\text { Drugs use has increased } \\
\text { due to tourism }\end{array}$} & Fully agree & 4 & & & \\
\hline & Agree & 17 & & & \\
\hline & Undecided & 27 & 11.698 & 4 & .020 \\
\hline & Disagree & 36 & & & \\
\hline & Fully disagree & 16 & & & \\
\hline & Fully agree & 14 & & & \\
\hline The high number of tourists & Agree & 28 & & & \\
\hline moves residents away from & Undecided & 17 & 5.266 & 4 & .261 \\
\hline public spaces & Disagree & 25 & & & \\
\hline & Fully disagree & 17 & & & \\
\hline & Fully agree & 17 & & & \\
\hline The interaction between & Agree & 51 & & & \\
\hline residents / workers and & Undecided & 22 & 8.938 & 4 & .063 \\
\hline tourists is good & Disagree & 8 & & & \\
\hline & Fully disagree & 2 & & & \\
\hline
\end{tabular}

Data also brings evidence that some negative impacts are starting to be felt, such as the detriment of quality of life of residents, the fact that traditional residents are moving away from the city centre, and the increased of traffic, similarly to Afthanorhan et al. (2017) conclusions. On the other hand, some benefits stand out. Besides the fact that tourism growth is not leading to usual problems of drugs, prostitution, and crime, it increased the number and quality of cultural activities and 
promotes the preservation of cultural heritage, confirming the findings of Amuquandoh (2010) and of Brida, Disegna \& Osti (2014). Residents also feel that there is a good and positive interaction between them and tourists, conversely to Brida et al. (2014) findings that support that tourism development can lead to increase stress on the community and to a negative change in the destinations' socio-cultural and physical characteristics.

As previously mentioned, the little empirical evidence found on the specific problems and feelings of cities' residents towards the excessive growth of tourism led to the development of an alternative methodology. Several documentaries were analysed, followed by content analysis to extract statements that are representative of these mostly negative feelings. These statements were presented to the respondents, to analyse their compliance in a scale of 'fully agree' to 'fully disagree' (Table 4).

Table 4 includes the results of this inquiry. Overall, the local community of the historic centre of Porto does not comply with the majority of the perceptions of residents of overcrowded tourism cities such as Barcelona or Venice. However, it is noticeable that $54 \%$ believe that there is a de-characterisation of local commerce and a subsequent loss of authenticity, $52 \%$ believe that housing prices are high and an overwhelming $83 \%$ feels it is impossible to rent or buy a house in the city centre. The rising cost of living is starting to affect the residents and local workers. Mann-Whitney test reported no statistically significant differences in the responses of those working in tourism, and those who do not directly benefit from the industry (Sig. = .082). Both groups present similar responses, which allows to refute Hypothesis 3 (Local community members that work or benefit from tourism have more positive feelings and attitudes towards it). The feelings towards tourism development are mostly positive, independently of individuals having a direct financial relation to the industry.

\begin{tabular}{|l|l|c|}
\hline Statements & $\begin{array}{c}\text { Level of } \\
\text { agreement }\end{array}$ & $\%$ \\
\hline & Fully agree & 10 \\
& Agree & 19 \\
"This is not a city to live in. It's a theme park " & Undecided & 13 \\
& Disagree & 35 \\
& Fully & 24 \\
& disagree & \\
\hline "The massification of tourism means that living & Fully agree & 11 \\
here, for the residents, becomes intolerable" & Agree & 27 \\
& Undecided & 19
\end{tabular}




\begin{tabular}{|c|c|c|}
\hline \multirow[t]{3}{*}{ Statements } & $\begin{array}{c}\text { Level of } \\
\text { agreement }\end{array}$ & $\%$ \\
\hline & Disagree & 25 \\
\hline & $\begin{array}{l}\text { Fully } \\
\text { disagree }\end{array}$ & 18 \\
\hline \multirow{5}{*}{$\begin{array}{l}\text { "Tourism will not last forever and is destroying } \\
\text { our lifestyles" }\end{array}$} & Fully agree & 13 \\
\hline & Agree & 22 \\
\hline & Undecided & 21 \\
\hline & Disagree & 27 \\
\hline & $\begin{array}{l}\text { Fully } \\
\text { disagree }\end{array}$ & 17 \\
\hline \multirow{5}{*}{$\begin{array}{l}\text { "Everything turned into tourist shops. It's } \\
\text { ridiculous", }\end{array}$} & Fully agree & 15 \\
\hline & Agree & 39 \\
\hline & Undecided & 16 \\
\hline & Disagree & 23 \\
\hline & $\begin{array}{l}\text { Fully } \\
\text { disagree }\end{array}$ & 8 \\
\hline \multirow{5}{*}{$\begin{array}{l}\text { "I can no longer be rested in the downtown } \\
\text { streets. There is always a lot of noise and it is } \\
\text { unsafe. " }\end{array}$} & Fully agree & 4 \\
\hline & Agree & 13 \\
\hline & Undecided & 14 \\
\hline & Disagree & 52 \\
\hline & $\begin{array}{l}\text { Fully } \\
\text { disagree }\end{array}$ & 17 \\
\hline \multirow{5}{*}{ "We, the residents, have lost the public spaces" } & Fully agree & 6 \\
\hline & Agree & 25 \\
\hline & Undecided & 14 \\
\hline & Disagree & 40 \\
\hline & $\begin{array}{l}\text { Fully } \\
\text { disagree }\end{array}$ & 15 \\
\hline \multirow{5}{*}{$\begin{array}{l}\text { "We do not receive tourists who want to know } \\
\text { the residents' way of life. They want to move } \\
\text { from store to store to consume constantly" }\end{array}$} & Fully agree & 6 \\
\hline & Agree & 25 \\
\hline & Undecided & 15 \\
\hline & Disagree & 39 \\
\hline & $\begin{array}{l}\text { Fully } \\
\text { disagree }\end{array}$ & 15 \\
\hline \multirow{5}{*}{$\begin{array}{l}\text { "There is no traditional trade and prices are } \\
\text { rising" }\end{array}$} & Fully agree & 13 \\
\hline & Agree & 39 \\
\hline & Undecided & 20 \\
\hline & Disagree & 18 \\
\hline & $\begin{array}{l}\text { Fully } \\
\text { disagree }\end{array}$ & 10 \\
\hline \multirow{5}{*}{$\begin{array}{l}\text { "It is impossible to pay a house rent in the city } \\
\text { centre" }\end{array}$} & Fully agree & 54 \\
\hline & Agree & 29 \\
\hline & Undecided & 11 \\
\hline & Disagree & 6 \\
\hline & $\begin{array}{l}\text { Fully } \\
\text { disagree }\end{array}$ & 0 \\
\hline
\end{tabular}

Finally, respondents were asked to freely list the negative and positive impacts of tourism development in the city, which further confirms the above-mentioned findings. Based on the results presented on table 5, rising prices (of housing and the 
cost of living) are the factors that most concern the community. Data confirms the findings of literature review, where negative economic consequences are usually associated with price inflation in the location where tourism is consumed (Afthanorhan et al., 2017; Andereck et al., 2005; Ardahaey, 2011). Still, according to the perception of the residents of Porto, it is understood that tourism usually leads to an increase in pollution, destruction of ecosystems, increase of garbage and traffic (Andereck et al., 2005), which arises the issue of environmental sustainability of tourism in cities, usually neglected by both academy and public authorities.

\begin{tabular}{l|c|}
\hline $\begin{array}{l}\text { Negative impacts that tourism has brought to } \\
\text { community life }\end{array}$ & $\%$ \\
\hline Increased cost of living & 18.8 \\
Overcrowding of services & 17.4 \\
Housing price increase & 12.1 \\
Increased traffic & 9.4 \\
Tourists are prioritized against residents & 8.1 \\
Noise problems & 7.4 \\
Unsafety & 5.4 \\
Closing of traditional commerce & 4.7 \\
Loss of identity & 4.7 \\
\multicolumn{2}{c}{ Table 5. Negative impacts mentioned by respondents } \\
\hline Source: own elaboration.
\end{tabular}

Table 6 pinpoints that the development of tourism activities in some regions can lead to the improvement of residents' quality of life by creating better local facilities and infrastructures which can, in turn, lead to better education, health care, employment opportunities and income; more cultural and social events available to the local population; conservation of the local cultural heritage of a region; urban areas that were in decline may be revitalized, which was what occurred in Porto and validates the findings of Afthanorhan et al. (2017) and of Zaei \& Zaei (2013).

\begin{tabular}{l|c|}
\hline $\begin{array}{l}\text { Positive impacts that tourism has brought to } \\
\text { community life }\end{array}$ & $\%$ \\
\hline $\begin{array}{l}\text { Urban rehabilitation and valorisation of the city (services } \\
\text { and public spaces) }\end{array}$ & 35.8 \\
Increase of cultural supply and of city's life & 33.1 \\
Economic development & 24.5 \\
Increase in employment & 22.5 \\
Interaction with other cultures & 19.2 \\
\hline \multicolumn{2}{c}{ Table 6. Positive impacts mentioned by respondents } \\
\multicolumn{1}{c}{ Source: own elaboration. }
\end{tabular}


If, on one hand, $74 \%$ of the respondents say they agree with the development of tourism in the city of Porto, $83 \%$ of the same individuals say that it is impossible to pay rent in the historic city centre. Just as $81 \%$ of respondents agree that tourism has driven the frequent creation of cultural activities, $60 \%$ admit that tourism is responsible for the departure of the residents. From the results, it is concluded that the community of Porto begins to question the ethics related to tourism growth but admits that this boom was fundamental to improve other important aspects of their quality of life, such as safety, cleanliness, heritage conservation and the dynamics of the city. As it may be seen, opinions are divided, and it is still difficult to find consensus. However, it is common for individuals working in tourism to respond more positively, with less concern about the negative impacts of the sector. To sum up, the type of negative impacts felts by the respondents (residents and workers) do not appear to be the same, or at least are not perceived with the same intensity, when compared to urban tourism destinations in more advanced stages of development, namely where massification is already a constant for several years. Thus, hypothesis 4 can be confirmed, and it can be concluded that urban residents' attitudes towards tourism depends on its stage of development.

\section{DISCUSSION}

\section{1) A SOCIALLY SUSTAINABLE DEVELOPMENT PROPOSAL}

From the literature review, it may be concluded that a sustainable tourism destination should involve local community, making residents feel part of the tourism project, with the strengthening of the positive relationship between tourists and residents and assuring that the local also collect the benefits of tourism growth. However, other aspects emerge as important for the common well-being, such as the awareness of tourists about local customs and civic and environmental care, to create and strengthen a sense of community and to facilitate access to financial means for community-based tourism projects. There may not be a single model for the sustainable development of tourism in cities, since it will be highly dependent on the destination's growth rate, on the characteristics of local communities, on the 
economic importance of tourism against other economic activities, on the local culture and hospitality, nature of tourism resources, among others. However, in order to advance a development model, it is crucial to be aware of the main negative and positive impacts, from the perspective of the community. Thus, the proposed guidelines resulting from this research are based on the responses given by the enquiries especially in what concerns the negative impacts felt by them, and on the assumption, that in the case of Porto and at this point, tourism has been providing more positive than negative effects on local community, as concluded by the collected data.

\begin{tabular}{|l|l|}
\hline Proposed measures & Goal \\
\hline & $\begin{array}{l}\text { Control the short-term rental, allowing the } \\
\text { population to live in the centre of the city, } \\
\text { 1) Regulation of local accommodation } \\
\text { and hotel units; }\end{array}$ \\
$\begin{array}{l}\text { peripheries due to occupation of buildings } \\
\text { by tourism. This will also prevent the loss } \\
\text { of identity. }\end{array}$ \\
\hline
\end{tabular}

2) Support for the establishment of the community in the historic centre;

To control gentrification, to avoid residents from moving away, to prevent loss of identity.

3) Support for the development of traditional trade;

Keep alive the commercial tradition of the city centre; avoid the closing of traditional shops.

4) Create synergies with small local businesses;

Fairer distribution of tourism profits; avoid the closing of traditional shops.

To foster the positive relationships

5) Awareness of tourists to the habits and traditions of the community; established between tourists and residents, considered as one positive impact of tourism; promote greater mutual respect.

With the profits of the fees, increase

6) Rethinking the application of the amount collected by the tourist tax; investments in resident community, particularly in the scope of social housing.

Support and invest in local initiative if

7) Support to the community for the these projects focus on community inclusion. This will maintain traditional creation of new businesses; commercial activities, authenticity and avoid precarious employment.

8) Adoption of measures to assure that locals can access products and services at a fairer price (e.g. controlled housing prices for residents, discount cards in Control the increase in the cost of living, allowing the community to maintain quality of life. traditional establishments); 
9) Increase of public transport line;

10) Frequent policing;
Control overcrowding in public transport;

Maintain safety levels and ensure that residential areas are not hampered by noise at night;

Table 7. Measures to be implemented in tourism cities to assure its sustainable development Source: own elaboration.

There are several key factors to consider when implementing any sustainable development model for tourism in cities. As above-mentioned, tourism development in Porto has reached a stage where positive impacts surpass the negatives, which means that with the implementation of the right measures, aligned with the perceptions, attitudes and feelings of the population, it is possible to reach a sustainable development model for tourism cities. The proposed guidelines are based on the possibility of improving the residents and workers quality of life, promotes the Integration of small businesses into tourism as well as the integration of the community in the tourist industry. Measures are thus proposed to control the gentrification, and to assure greater social justice in tourist destinations. This may help to overcome the mentioned feeling of detriment of quality of live, the exodus of locals to the city's peripheries due to the occupation of housing by tourism industry and to the increase in housing prices.

One of the main strengths of the guidelines is the preservation of the authenticity and cultural identity of the city of Porto and ensuring the dignity of cultural traditions, considering that the loss of identity is mentioned as a negative effect of tourism development. This way, the application of the measures can bring opportunities to the positioning of Porto as a reference destination for being sustainable and for its support to the community. On the other hand, these guidelines present weaknesses and threats such as difficulties in the practical implementation of some measures due to the costs they may represent and the associated bureaucratic aspects; further regulation can discourage investment, and with the implementation of tourist taxes and the reduction of short-term rents, the tourist can choose cheaper destinations.

Thus, the proposed guidelines may be on the basis for urban tourism sustainable development. They are based on very important values, such as equity, social justice, and inclusion of the community in the city's tourism project. It is therefore believed that the implementation of measures like those outlined below may contribute to the creation of a higher synergy involving small traditional businesses. 
Bearing this in mind, it is believed that there should be a political resistance to real estate pressures. It is fundamental that the resident is always prioritized, and that the welfare of the community is unconditionally assured. This will contribute to the emergence of a social structure capable of sustaining the significant tourism growth in Porto and in similar cities worldwide.

This research brings important contributions. First, it analyses tourism development impacts in urban settings in an early stage of development, which supports the design and implementation of preventive measures, instead of reactive and damage control, often ineffective, measures. It also adopts the perspective of local community. It then advances a set of guidelines, based on the survey's results that translate residents' perceptions, and on literature review. These may be transformed into measures implementable by local public and private authorities, in order to assure the social sustainability of tourism development in historic city centres in similar stages of development.

\section{CONCLUSIONS}

Urban tourism is a worldwide trend, and this is raising disagreements about the excess of tourists and the negative consequences that it is bringing to local communities. Displaced residents to give way to tourism activities, rising prices, touristification, loss of authenticity, among other issues, are being discussed by academics, politicians, and practitioners. There is an urgent need to develop models that assure the sustainable development of touristic cities. The feelings, understandings, and opinions of residents of Porto, a city where tourism is growing fast, but where negative impacts are still very reduced, can bring important insights on how these socially sustainable models should be designed and implemented. Bearing this in mind, the present research aims at analysing the impacts of tourism development in urban contexts and how they are felt by local communities comprising residents and workers). Based on the feelings and understandings of these individuals, it is intended to propose socially sustainable development guidelines for this type of setting, considering that most of tourism sustainable development models are focused on environmental issues and applied to natural, protected, or coastal destinations. In order to do so, the attitudes and feelings of 
residents and workers towards tourism impacts were analysed. Collected data allowed to validate the defined hypothesis, which were defined on the basis that having a tourism-related professional occupation could lead to different attitudes towards these impacts.

Overall, this research demonstrates that, despite the awareness of some negative impacts, the community is satisfied with tourism development in the city and still presents a positive attitude towards it. The rehabilitation of public spaces, the increased security, the diversification and rise of cultural offerings, the increase in families' income, the creation of employment opportunities, are situations that positively benefit the population. However, the residents' concern about the drastic increase in the cost of living and the issue of gentrification is notorious. It is also important to note that respondents reveal that there is a sense of injustice in the distribution of tourism profits, as more than half believe that tourism benefits only a certain group of people. The fact of having a tourism-related profession only influences the perceptions of economic impacts. Respondents that perform functions linked to tourism, or that have close family members doing so, are more positive towards economic impacts resulting from tourism development, than the others. Working or not in tourism does not lead to differences in opinions about the sociocultural impacts.

The results of the empirical study allowed advancing a set of guidelines that should be on the basis of a model that assure the socially sustainable development of tourism in cities. These are preventive and non-reactive measures aiming to lead to a better planning of tourism development and that place residents in the forefront for a sustained and happy growth of destinations.

\section{1) RESEARCH LIMITATIONS}

It is acknowledged that one of the main limitations of this research is the fact that is an exploratory study and, thus, may have limited generalization of findings, in result of the small size of the sample. A higher number of respondents could strengthen the conclusions and could better illustrate the perceptions of the local communities towards the destinations' development. The fact that the last censuses refer to the year 2011 and knowing that in these six years the city has changed drastically appears as a limitation, since it is based on numbers of inhabitants that we 
know may be outdated. It is believed that a larger and probability sample could strengthen the findings as it would be more representative of the population. Qualitative studies might also bring additional and relevant results to understand the perceptions and attitudes of local community towards tourism growth. In addition, given that this is a matter under discussion at European and national level, it could have been important to conduct interviews with several organisations and experts in order to understand different perspectives and to know if measures are being considered to minimize the negative impacts of the tourism in cities worldwide.

\section{2) SUGGESTIONS FOR FUTURE RESEARCH}

The topic of overcrowding in cities and its impacts is a recent debate. Thus, there are several avenues of thought and research that should be pursued in order to bring additional contributions. More comparative studies should be conducted, between European cities experiencing the same problems and the type of strategies being developed to address these issues. In this paper, several guidelines to assure a socially sustainable tourism development in cities are advanced. However, it would be of great interest to deepen this development proposal with the creation of i) indicators of sustainable development applied to the specific case of historic cities that allow its monitoring; and ii) a structured and integrated development model including the linkages between all stakeholders and the processes underlying it. This would allow to continuously analyse the development process and, according to the identified paths, to change the development plans and implement effective measures aimed at constant concern with the resident community. As time passes and the destinations evolve, different impacts will occur, and the residents' perceptions may change. It is thus fundamental to conduct longitudinal studies to monitor local community's feelings and preservation of their quality of life.

\section{References}

Afthanorhan, A.; Awang, Z.; Fazella, S. Perception of Tourism Impact and Support Tourism Development in Terengganu, Malaysia. Social Sciences, Vol. 6, No 106, 2017, pp. 1-11. 
Amuquandoh, F.E. Residents' perceptions of the environmental impacts of tourism in the Lake Bosomtwe Basin, Ghana. Journal of Sustainable Tourism, Vol. 18, No 2, 2010, pp. 223-238.

Andereck, K.L., Valentine, K.M., Knopf, R.C.; Vogt, C.A. Residents' perceptions of community tourism impacts. Annals of Tourism Research, Vol. 32, No 4, 2005, pp. 1056-1076.

Ardahaey, F.T. Economic impacts of tourism industry. International Journal of Business and Management, Vol. 6, No 8, 2011, pp. 208-209.

Ashworth, G.; Page, S.J. Urban tourism research: Recent progress and current paradoxes. Tourism Management, Vol. 32, No 1, 2011, pp. 1-15.

Belhassen, Y.; Caton, K.; Stewart, W.P. The search for authenticity in the pilgrim experience. Annals of Tourism Research, Vol. 35, No 3, 2008, pp. 668-689.

Bexiga, S. Peso do turismo na economia portuguesa em trajetória ascendente atinge os $7 \%$. Jornal Económico, December $7^{\text {th }}$ 2017. Available at: https://jornaleconomico.sapo.pt/noticias/peso-do-turismo-na-economia-portuguesaem-trajetoria-ascendente-atinge-7-242294 [accessed 4 September 2019].

Blank, U. Research on Urban Tourism Destinations. In: J.R.B. Ritchie; C.R. Goeldener (Eds.). Travel, Tourism and Hospitality Research: A Handbook for Managers and Researchers. New York: Wiley, 1994, pp. 181-193.

Botelho, A.C.B.; Egrejas, M.; Bartholo, R. The touristification of the port area in Rio de Janeiro, Brazil: for a Located Tourism in Morro da Conceição. Revista Brasileira de Pesquisa em Turismo, Vol. 8, No 2, 2014, pp. 286-300.

Brida, J.G.; Disegna, M.; Osti, L. Residents' perceptions of tourism impacts and attitudes towards tourism policies. Tourismos: An International Multidisciplinary Journal of Tourism, Vol. 9, No 1, 2014, pp. 37-71. 
Brouder, P.; loannides, D. Urban tourism and evolutionary economic geography: Complexity and co-evolution in contested spaces. Urban Forum, Vol. 25, No 4, 2014, pp. 419-430.

Choi, H.S.; Sirakaya, E. Measuring residents' attitude toward sustainable tourism: development of sustainable tourism attitude scale. Journal of Travel Research, Vol. 43, 2005, pp. 380-394.

Dwyer, L.; Edwards, D.; Mistilis, N.; Roman, C.; Scott, N. Destination and enterprise management for a tourism future. Tourism Management, Vol. 30, No 1, 2009, pp. 6374.

ECM - European Cities Marketing. European Cities Marketing Benchmarking Report. 2018, Dijon: ECM.

Füller, H.; Michel, B. 'Stop being a tourist!' New dynamics of urban tourism in BerlinKreuzberg. International Journal of Urban and Regional Research, Vol. 38, No 4, 2014, pp. 1304-1318.

Gravari-Barbas, M.; Guinand, S. Tourism and Gentrification in Contemporary Metropolises: International Perspectives. New York: Routledge, 2017.

Guerreiro, M.M.; Mendes, J. d. C.; Valle, P.O.; Silva, J.A. Análise da satisfação dos residentes com o turismo: o caso de uma área-destino no Algarve, Portugal. Turismo em Análise, Vol. 19, No 3, 2008, pp. 488-504.

Herzer, H. Acerca de la gentrificación. In: H. Herzer (Ed.). Con el Corazón Mirando al Sur: Transformaciones en el sur de la ciudad de Buenos Aires. Buenos Aires: Espacio, 2008, pp. 19-44.

INE. Statistical Yearbook 2016. Lisbon: INE, 2017.

INE. Statistical Yearbook 2006. Lisbon: INE, 2007. 
Issa, Y.; Dencker, A. Processos de Turistificação: Dinâmicas de inclusão e exclusão de Comunidades Locais. Paper presented at the IV SeminTUR - Seminário de Pesquisa em Turismo do MERCOSUL, Universidade de Caxias do Sul, Brasil, 2006.

Jeon, M.M.; Kang, M.M.; Desmarais, E. Residents' perceived quality of life in a cultural-heritage tourism destination. Applied Research in Quality of Life, Vol. 11, No 1, 2016, pp. 105-123.

Kim, H.; Jamal, T. Touristic quest for existential authenticity. Annals of Tourism Research, Vol. 34, No 1, 2007, pp. 181-201.

Lansky, D. A cidade pode ter turistas, mas os turistas não podem ter a cidade. In C. Tomás (Writer), Jornal Expresso, May $27^{\text {th }}$ 2017. Available at: https://expresso.pt/sociedade/2017-05-27-A-cidade-pode-ter-turistas-mas-osturistas-nao-devem-ter-a-cidade\#gs.62ww0o [accessed 4 September 2019].

Li, X.; Wan, Y.P. Residents' attitudes toward tourism development in Macao: a path model. Tourism Analysis, Vol. 18, 2013, pp. 443-455.

Lundberg, E. The importance of tourism impacts for different local resident groups: A case study of a Swedish seaside destination. Journal of Destination Marketing \& Management, Vol. 6, No 1, 2017, pp. 46-55.

Martín, J.M.M.; Martínez, J.M.G.; Fernández, J.A.S. (2018). An analysis of the factors behind the citizen's attitude of rejection towards tourism in a context of overtourism and economic dependence on this activity. Sustainability, Vol. 10, No 8, 2018, pp. 118.

Mendes, L. Gentrificação e políticas de reabilitação urbana em Portugal: uma análise crítica à luz da tese rent gap de Neil Smith. Cadernos Metrópole, Vol. 16, No 32, 2014, pp. 487-511. 
Minoia, P. Venice reshaped? Tourist gentrification and sense of place. In: N. Bellini; C. Pasquinelli (Eds.). Tourism in the City: Towards an Integrative Agenda on Urban Tourism. New York: Springer, 2017, pp. 261-274.

Nawijin, J. Determinants of daily happiness on vacation. Journal of Travel Research, Vol. 50, No 5, 2011, pp. 559-566.

Nunkoo, R.; Gursoy, D. Residents' support for tourism: an identity perspective. Annals of Tourism Research, Vol. 39, No 1, 2012, pp. 243-268.

Paskaleva-Shapira, K. New paradigms in city tourism management: Redefining destination promotion. Journal of Travel Research, Vol. 46, No 41, 2007, pp. 108114.

Pearce, D.G. An integrative framework for urban tourism research. Annals of Tourism Research, Vol. 28, No 4, 2001, pp. 926-946.

Pham, L.H.; Kayat, K. Residents' perceptions of tourism impact and their support for tourism development: The case study of Cuc Phuong National Park, Ninh Binh province, Vietnam. European Journal of Tourism Research, Vol. 4, No 2, 2011, pp. 123-146.

Postma, A.; Schmuecker, D. Understanding and overcoming negative impacts of tourism in city destinations: conceptual model and strategic framework. Journal of Tourism Futures, Vol. 3, No 2, 2017, pp. 144-156.

Público. Estalou a guerra ao turismo em Barcelona e os primeiros alvos foram autocarros e bicicletas. Público, August $1^{\text {st }}$ 2017. Available at: https://www.publico.pt/2017/08/01/mundo/noticia/abriuse-uma-guerra-ao-turismo-embarcelona-e-os-primeiros-alvos-foram-autocarros-e-bicicletas-1781075 [accessed 4 September 2019]. 
Ramires, A.; Brandão, F.; Sousa, A. Motivation-based cluster analysis of international tourists visiting a World Heritage city: the case of Porto, Portugal. Journal of Destination Marketing and Management, Vol. 8, No 1, 2018, pp. 49-60.

Ribeiro, L.R.; Pinheiro, M. Turismo dá gás à retoma mas Portugal fechou o ano a abrandar. Diário de Notícias, February $15^{\text {th }}$ 2018. Available at: https://www.dn.pt/dinheiro/interior/turismo-da-gas-a-retoma-mas-portugal-fechou-oano-a-abrandar-9119063.html [accessed 4 September 2019].

Rogerson, C.M.; Rogerson, J.M. Urban tourism destinations in South Africa: Divergent trajectories 2001-2012. Urbani izziv, No 25 (Supplement), 2014, pp. 189203.

Seraphin, H.; Yallop, A.C.; Capatîna, A.; Gowreesunkar, V.G. Heritage in tourism organisations' branding strategy: the case of a post-colonial, post-conflict and postdisaster destination. International Journal of Culture, Tourism and Hospitality Research, Vol. 12, No 1, 2018, pp. 89-105.

Seraphin, H.; Sheeran, P.; Pilato, M. Over-tourism and the fall of Venice as a destination. Journal of Destination Marketing \& Management, Vol. 9, 2018, pp. 374376.

Sirgy, M.J.; Widgery, R.N.; Lee, D.J.; Yu, G.B. Developing a measure of community well-being based on perceptions of impact in various life domains. Social Indicators Research, Vol. 96, No 2, 2010, pp. 295-311.

Skoll, G.R.; Korstanje, M. Urban heritage, gentrification, and tourism in Riverwest and El Abasto. Journal of Heritage Tourism, Vol. 9, No 4, 2014, pp. 349-359.

UNWTO. Global report on food tourism. Madrid: UNWTO, 2012.

UNWTO; SNV. Manual on Tourism and Poverty Alleviation, Practical Steps for Destinations. Madrid: UNWTO, 2010. 
Uysal, M.; Perdue, R.; Sirgy, R. Handbook of tourism and quality-of-life research: Enhancing the lives of tourists and residents of host communities. Netherland: Springer, 2012.

Veal, A.J. Research Methods for Leisure and Tourism. A Practical Guide. London: Pitman, 2006.

Wise, N. Outlining triple bottom line contexts in urban tourism regeneration. Cities, Vol. 53, 2016, pp. 30-34.

Yu, C.P.; Chancellor, H.C.; Cole, S.T. Examining the effects of tourism impacts on resident quality of life: evidence from rural midwestern communities in USA. International Journal of Tourism Sciences, Vol. 11, No 2, 2011, pp. 161-186.

Zaei, M.E.; Zaei, M.E. The impacts of tourism industry on host community. European Journal of Tourism Hospitality and Research, Vol. 1, No 2, 2013, pp. 12-21.

Article info: Received 17/04/2019. Accepted 04/09/2019. Refereed anonymously. 